\title{
STRATEGI PENGEMBANGAN KOMODITAS STUDI TENTANG BUDAYA EKONOMI DI KALANGAN PENGUSAHA BATIK LAWEYAN
}

\author{
Erma Setiazwati \\ Program Studi Kebijakan Universitas Gadjah Mada \\ Email: setiawatierma@ymail.com \\ Irwan Abdullah \\ Fakultas IImu Budaya Univesitas Gadjah Mada \\ Lasiyo \\ Fakultas Filsafat Universitas Gadjah Mada
}

\begin{abstract}
Batik is part of Indonesian national culture and has been recognized by UNESCO as part of the world's cultural heritage. The village of Laweyan is home to one of the oldest and most central traditional batik industries in Indonesia. Batik Laweyan survives because of the community's efforts to develop a solid and adaptive economic culture. Batik production and trade have been key characteristics of the Laweyan community from the Pajang era until the present day.
\end{abstract}

Keywords: Cultural economics, Strategy Entrepreneur, Fashion Laweyan

\begin{abstract}
ABSTRAK
Batik merupakan ciri khas budaya bangsa Indonesia yang mendapat pengakuan dari UNESCO sebagai warisan budaya dunia. Kampung batik Laweyan merupakan kampung batik tertua dan menjadi pusat industri batik tradisional di Indonesia. Batik Laweyan bertahan karena berhasil mengembangkan suatu kultur ekonomi yang solid dan adaptif. Ciri khas komunitas kampung batik Laweyan dari mulai kerajaan Pajang sampai sekarang sebagai pedagang batik..
\end{abstract}

Kata kunci: Budaya ekonomi, Strategi Pengusaha, Batik Laweyan 


\section{PENGANTAR}

Batik merupakan salah satu budaya ciri khas bangsa Indonesia yang telah mendapat pengakuan dari UNESCO serta ditetapkan sebagai Warisan Kemanusiaan untuk Budaya Lisan dan Nonbendawi (Masterpieces of the Oral and Intangible Hertage of Humanity) sejak 2 Oktober 2009, serta mempunyai keunggulan komparatif dibidang ekonomi, sehingga diharapkan mampu meningkatkan kesejahteraan masyarakat (Prasetyo, 2010: 2).

Industri batik pada tahun 2006 berjumlah 48.287 unit usaha tersebar di 17 provinsi dan mampu menyerap tenaga kerja sebanyak 792.300 orang, sedangkan nilai produksi mencapai $\operatorname{Rp} 2,90$ triliun dan nilai ekspor US\$ 110 juta. Beberapa data menunjukkan bahwa Jawa Tengah memberikan kontribusi ekspor sebesar 30-35 persen dari ekspor nasional. Menurut Menteri Perindustrian bahwa industri batik tanah air memiliki nilai ekonomis cukup tinggi dan kontribusi positif terhadap produk domistik bruto nasional (PDB). Pada tahun 2008 industri batik nasional mencapai nilai ekspor US\$ 38 juta dan menyerap tenaga kerja 603 ribu, sedangkan unit usaha yang dipekerjakan melalui industri batik ini adalah sebanyak 50.315 unit. Industri kreatif kira-kira 7,9 persen PDB 2008 yaitu produk fesyen kirakira 25-27 persen dan 50 persen adalah berbasis batik (Prasetyo, 2010: 37-38).

Batik berkembang dan menyebar terutama di Pulau Jawa, misalnya yang dikenal dengan Batik Garut, Tasikmalaya, Ciamis, Pekalongan, Kedungwuni, Tegal, Banyumas, Purwokerto, Kudus, Demak, Surakarta, Yogyakarta, Juwana, Rembang, Lasem, dan Madura. Di Surakarta terdapat kampung batik tertua di Indonesia yaitu Kampung Laweyan dan perkembangan batik dimulai sejak kerajaan Pajang oleh Kyai Ageng Henis dengan mengajarkan membatik dan menyebarkan agama islam kepada santri-santrinya berkembang sampai sekarang. Kampung Laweyan merupakan kawasan sentra industri batik yang unik, spesifik, dan bersejarah (Mlayadipuro, 1984). Industri batik di kawasan ini mula- mula merupakan industri kerajinan rumah tangga dilakukan oleh kaum wanita yang sering disebut dengan istilah mbok mase. Pada tahun 1960-an hampir 90 persen warga Laweyan bekerja sebagai pembatik. Batik merupakan hasil karya seni tradisional yang banyak ditekuni masyarakat Laweyan sejak dulu hingga sekarang. Namun dalam perkembangannya pada tahun 1970-an, jumlah industri batik yang ada di Laweyan mengalami kemunduran karena produksi batik tulis dan batik cap di Laweyan tergeser dengan kehadiran batik printing yang mampu memproduksi secara massal dalam waktu cepat.

Kegagalan pengusaha pribumi di dalam bidang ekonomi disebabkan oleh sifat-sifat organisasi ekonomi yang tidak rasional. Di lain pihak, kegagalan pribumi lebih disebabkan oleh pengaruh struktural yang sedikit sekali memberi peluang kepada pedagang pribumi, baik sejak masa kolonial hingga sekarang ini (Abdullah, 1994:193).

Pengalaman dari perjalanan usaha batik Laweyan ini menjadikan sebagai guru yang paling berharga. Setelah tahun 2000-an para pengusaha batik, masyarakat, generasi muda Laweyan mempunyai gagasan untuk menjadikan Laweyan seperti pada masa kejayaan dulu. Mulailah bangkit kembali para pengusaha di Laweyan dengan ditandai tidak hanya memproduksi batik tulis dan batik cap saja, tetapi juga memproduksi batik printing. Setelah otonomi daerah diberlakukan, Pemerintah Kota Surakarta memiliki ruang untuk mengembangkan potensi daerah yang dimilikinya. Pada tahun 2004 Pemerintah Kota Surakarta berupaya membangkitkan kembali kejayaan industri batik di Laweyan melalui pencanangan kampung Laweyan sebagai kampung wisata batik. Pembentukan kawasan kampung wisata batik ini ditetapkan dengan Surat Keputusan (SK) Walikota Surakarta No.534.05/136-B/1/2004 tentang Panitia Pelaksanaan Pembentukan Kawasan Batik Laweyan (Suryanti, 2009:36)

Sejak dicanangkan sebagai kampung wisata batik, industri batik di kampung 
Laweyan semakin berkembang. Ini terjadi karena banyak wisatawan yang berkunjung untuk berbelanja batik sekaligus belajar membatik, serta menikmati bangunanbangunan peninggalan yang bersejarah. Secara tidak langsung membawa pengaruh positif pada perkembangan industri batik di Laweyan yang ditandai dengan meningkatnya omset penjualan.

Januari 2010, diberlakukannya CAFTA (China Asean Free Trade Area) di Solo batik produk China sudah mulai merambah ke pasar-pasar tradisional, tetapi perkembangan batik Laweyan tidak banyak mengalami penurunan (Karba'a,2010). Menurut Geertz tentang kebijakan-kebijakan pemerintah di bidang pembinaan Pengusaha Pribumi memperhitungkan perbedaan-perbedaan yang terdapat pada lembaga sosial budaya di masing-masing daerah. Ketidaksuksesan atau kurangnya sukses yang diperoleh Pemerintah dalam usaha-usaha pembinaan pengusaha pribumi tersebut berasal dari dua hal sebagai berikut :

1. Dari kebijaksanaan-kebijaksanaan pembinaan pengusaha pribumi yang dirumuskan dan dilaksanakan oleh pihak pemerintah sendiri sangatlah menyolok perbedaannya antara sasaran yang dituju dan hasil yang diperoleh muncul karena kebijaksanaankebijaksanaan pemerintah sifatnya terlalu umum, terlalu menghendaki hasil-hasil nyata yang segera, dan kurang terkoordinir atau terfokuskan.

2. Dari kelemahan-kelemahan intern pihak pengusaha pribumi sendiri. Artinya bahwa para pengusaha pribumi rupanya masih terjerat oleh beberapa faktor penghambat, dalam usaha mereka untuk memanfaatkan kebijakasanaankebijaksanaan Pemerintah. Geertz telah menunjukkan, betapa faktor-faktor penghambat ini sangat berhubungan dengan latar belakang sosial-budaya dari masing-masing daerah dari mana golongan-golongan ini muncul. Tampaknya, perubahan-perubahan dalam hal ini harus terjadi sebelum golongan ini dapat memanfaatkan kebijaksanaan-kebijaksanaan pemerintah. Usaha-usaha tambahan tentunya dapat juga dikerjakan oleh pemerintah untuk mendorong adanya perubahan-perubahan ini (Geertz, 1977: 27).

Tradisionalitas atau struktur organisasi kerja keluarga adalah mirip dengan kegiatan-kegiatan petani kecil. Dengan mengemukakan alasan bahwa sifat-sifat usaha keluarga sebagai berikut:

1) Input-inputnya (tenaga kerja dan hasil antara) amat saling melengkapi satu sama lain dan/sangat mudah diganti oleh anggota-anggota dalam keluarga.

2) Terlepas dari pemusatan tenaga kerja yang lebih luas yang dilembagakan secara sosial pada saat tertentu dalam proses produksi, ada suatu kecenderungan untuk menghindari penerimaan tenaga kerja melalui pasar.

3) Keadilan dalam distribusi yang penuh dengan kalangan anggota-anggota keluarga untuk memperoleh pembagian hasil (Sajogyo dalam tulisan de Vries, 1982:45).

Setiap ciri tersebut diperinci lebih lanjut:

1) Sifat saling melengkapi acapkali dilembagakan dalam peran-peran tertentu penggarapan tanah, penanaman, penyiangan, memintal, menenun, dan seterusnya. Anak laki-laki mengurus kerbau, yang digunakan orang dewasa di sawah ini. Ini nampaknya statis, tetapi bila perlu atau bila ada kesempatan, peran-peran tersebut dapat digantikan dengan mudah.

2) Pemutusan tenaga kerja diperlukan bagi pekerja kelompok dalam perburuan. Penangkap ikan, persiapan tanah ladang. Demikian pula dalam pertanian yang sifatnyalebihindividual, regu-regu penanaman atau yang memanen bekerja menurut pola yang teratur, acapkali dengan tingkatan upah yang ditetapkan 
secara tradisional. Penerimaan tenaga kerja yang lebih mantap acapkali dalam bentuk penerimaan anggota baru dalam keluarga. Dengan cara mengangkat anak melalui perkawinan seseorang anggota keluarga.

3) Keadilan distributif. Apabila hasilnya cukup bagi setiap orang. Semuanya akan menerima bagian yang "pantas", mungkin tidak sama. Apabila bahan makanan atau sumber-sumber lain tidak mencukupi, maka "para pencari nafkah" atau "anak" didahulukan. Hal ini berbeda dari satu kebudayaan kepada kebudayaan yang lain. Orangorang yang lebih tua atau ibu rumah tangga bisa saja mendapat bagian paling akhir.

Sistem ekonomi kerakyatan bahwa rakyat dapat berperan sebagai produsen, konsumen, atau pelaku pasar. Sebagai produsen, rakyat berperan menghasilkan atau memproduksi barang dan jasa. Sebagai konsumen, rakyat berperan sebagai pemakai barang dan jasa tersebut. Sedangkan sebagai pelaku pasar, rakyat berperan menjamin lancarnya hubungan produsen dan konsumen. Rakyat mengendalikan demand dan supply barang dan jasa di pasar. Pembangunan yang dilaksanakan saat ini dirasa belum sepenuhnya berhasil menyejahterakan rakyat. Salah satu penyebabnya adalah kurang dilibatkannya masyarakat dalam pembangunan. Selama ini masyarakat hanya diperlakukan sebagai obyek pembangunan. Oleh karena itu, perlu diterapkan pendekatan baru yaitu pembangunan partisipatif atau disebut juga strategi pemberdayaan masyarakat. Dalam pendekatan ini, masyarakat diperlakukan sebagai subyek pembangunan dan pemerintah berperan sebagai fasilitator. Kemampuan masyarakat mengelola ekonominya memungkinkan terjadinya perubahan struktur sosial masyarakat. Proses perubahan tersebut berawal dari penciptaan lapangan kerja melalui proses produksi. Hal ini dapat meningkatkan penghasilan dan kesejahteraan masyarakat (Sumodiningrat, 2008: 176-184).

Pertumbuhan ekonomi adalah hasil dari suatu revolusi di bidang kehidupan ekonomi, yang pada akhirnya akan mendesakkan suatu gabungan kekuatan yang kritis dari berbagai variabel ekonomi - "critical mass" yang akan menimbulkan ada atau tidaknya proses lepas landas- atau "take-off"- di dalam pertumbuhan ekonomi.

Ada tiga masalah sosial yang fundamental yaitu masalah yang pertama adalah tatanan, di zaman pertengahan keyakinan akan Tuhan mengatur dan memerintah sangatlah hidup. Pertama, tatanan itu terwujud tidak saja di dalam penataan golongan-golongan di alam feodal, tetapi juga tepat di dalam realitas khas civil society. Gambaran Tuhan mulai hilang dari gambaran ilmiah mengenai dunia, sehingga harus dicari penjelasan-penjelasan ilmiah mengenai dunia, sehingga harus dicari penjelasan-penjelasan alamiah yang lain tentang tatanan itu. Kedua, Perubahan merupakan masalah fundamental yang kedua timbul dari konfrontasi dengan perubahanperubahan sosial yang radikal. Masyarakat waktu itu adalah suatu masyarakat yang sedang berubah. Dari mana datangnya perubahan ini? Bagaimana perbandingan perubahan itu dengan stabilitas tata dan rutinitas? Juga bagi masalah jawaban, yaitu (1) masyarakat pada hakekatnya adalah stabil, tetapi secara rutin muncul faktorfaktor pengganggu yang mengakibatkan perubahan. (2) justru merupakan lawan pertama. Ketiga, Ketidaksamaan bahwa di zaman Pertengahan sesungguhnya sama sekali tidak ada kesamaan. Golongangolongan sangat tidak sama satu dengan lainnya, baik dari segi politik, yuridis, maupun sosial. Tetapi ketidaksamaan ini bagi kebanyakan orang tidak menimbulkan masalah. Sebab, sudah pasti bahwa tiadanya kesamaan adalah kehendak Tuhan: keadaan ini termasuk tatanan yang memang telah diciptakan.( Laeyendecker, 1983, 53-57)

Teori-teori yang menjelasan penyebab terjadinya perubahan sosial dapat di bagi 
tiga kategori besar, yaitu (1) teori yang menganggap bahwa faktor biologis sebagai faktor dominan terjadinya perubahan sosial, (2), teori yang berpangkal pada faktor kebudayaan, dan (3) teori yang berpangkal pada faktor teknologi sebagai penyebab terjadinya perubahan sosial (Waliono,1983:48).

Menurut teori evolusi "survival of the fittest" oleh Darwin mengatakan bahwa hanya pengusaha atau organisasi yang paling adaptiflah yang dapat survive. Sebuah sistem akan mampu mempertahankan keberlangsungannya jika menjalankan fungsi Adaptation, Goal attainment, Integration, dan Latency (AGIL). Keberlangsungan sistem ini terutama diperuntukkan bagi sistem yang rapuh (vulnerable), terutama disebabkan faktor sosial ekonomi Parson (1953) dalam Hamilton (1983),

Porter (1997) mendefinisikan strategi sebagai upaya untuk mencapai keunggulan bersaing melalui suatu kesatuan rencana yang menyeluruh, komprehensif, dan terpadu yang diarahkan untuk mencapai tujuan perusahaan. Berbeda dengan Porter, Hamel, and Prahalad (1995) lebih menekankan arti strategi dalam konteks sisi kompetensi inti berdasarkan sudut pandang atau harapan para pelanggan di masa depan.

Istilahstrategidalamkonteks perusahaan pertama kali muncul pada dekade tahun 1970-an. Pada masa sebelumnya, dalam merumuskan suatu arah dan tujuan rencana ke depan perusahaan, pihak manajemen masih mengandalkan pada kekuatan internal (Ansoff and McDonnell, 1990). Seiring dengan meningkatnya dinamika lingkungan (enviroment of the turbulence) bisnis, maka diperlukan sistem yang lebih responsif terhadap masalah yang semakin kompleks, yaitu berupa perencanaan strategis (strategy planning) yang juga mempertimbangkan faktor-faktor eksternal.

Strategi pengembangan komoditas batik ini dipengaruhi dua faktor yaitu faktor internal dan faktor eksternal. Pengaruh faktor internal adalah faktor-faktor yang berada di kampung batik Laweyan yaitu struktur dan kultur sosial kampung Laweyan, lingkungan, dan keluarga pengrajin batik. Sedangkan pengaruh faktor ekternal adalah pemerintah (bantuan pemasaran, modal, dan pengadaan bahan baku), sektor perbankan, perguruan tinggi berupa bantuan desain, mutu produksi, pengusaha besar sebagai produsen.

\section{PEMBAHASAN}

\section{Komunitas dan Ciri Khas Batik Laweyan}

Pada awalnya semasa Kyai Ageng Henis bermukim di Laweyan, daerah tersebut merupakan nama sebuah pasar Lawe (bahan baku sandang) yang cukup ramai. Kedudukan pasar Laweyan pada saat itu cukup strategis karena didukung adanya sebuah bandar besar di sungai Kabanaran (Mlayadipuro,1984). Kampung Laweyan berkembang sebagai kampung santri yang taat menjalankan agama Islam. Hal ini terkait dengan keberadaan Kyai Ageng Henis pada akhir abad ke 16 di Laweyan. Ajaran agama Islam dari ulama besar tersebut secara turuntemurun menjiwai dunia kehidupan para santri di kampung batik tersebut. Arti dan makna kerja sebagai ibadah dan sillahturohmi mendatangkan barokah telah mengakar kedalam kehidupan sosial ekonomi para santri. Kawasan Kampung Laweyan berdasarkan bukti sejarah pada zaman kerajaan Pajang tahun 1546 mempunyai pola kawasan memusat. Pasar dengan Bandar Kabanarannya merupakan pusat kawasan, sedang pemukiman penduduk dengan home industry tenunnya merupakan kawasan pelingkup.

Industri batik baru muncul semasa kehadiran kraton Surakarta dan mencapai puncak kejayaannya pada tahun 1960-an. Laweyan kembali berkembang ketika industri batik cap mulai mampu membendung tekstil bermotif batik impor yang berharga murah. Lingkungan Laweyan sendiri terdapat penggolongan kelas sosial yang disebabkan oleh status kerja di perusahaan. Perusahaanperusahaan batik di Laweyan, secara tidak langsung membentuk sistem stratifikasi sosial yang disebut buruh dan majikan/ saudagar (Priyatmo, 2003:72). 
Buruh (pekerja) mencakup kriteria: tukang, buruh inti, pembantu rumah tangga, kuli ajeg (buruh tetap), dan kuli dinan (buruh harian) (De Kat Angelino, 1930:136). Tenaga buruh ini sebagai pekerja di perusahaan, dan sekaligus berfungsi sebagai pembantu rumah tangga majikan (saudagar). Saudagar atau majikan adalah kelas sosial atas. Untuk kelas atas ini masih di golongkan dalam urutan keluarga dengan sebutan sebagai berikut : "mbok mase sepuh" (nenek), "mas nganten sepuh" (kakek), mereka adalah orang tua dari ibu. Untuk selanjutnya "mbok mase" (ibu), "mas nganten" (ayah), "mas rara" (anak perempuan), "mas bagus" (anak laki-laki).

Pada tahun 1970 munculnya batik printing. Pertumbuhan batik printing terkait dengan kebijakan pemerintahan Orde Baru dalam hal ini mengejar pertumbuhan ekonomi. Sistem produksi manufaktur batik printing menghasilkan batik printing secara massal, kualitas halus, dan harga relatif murah dibandingkan batik cap. Persaingan tinggi antara batik printing dengan batik cap tidak dapat dihindari karena kedua jenis produk tersebut ditujukan pada segmen pasar yang sama. Dalam persaingan tersebut batik printing mempunyai nilai kompetitif yang lebih tinggi dibandingkan dengan produk batik cap. Akibatnya produk batik cap kalah bersaing baik dari kualitas maupun harga dan dampaknya sebagian besar perusahaan batik cap di Surakarta terpaksa harus tutup di era tahun 1970-an (Mahendra,2008:88).

Pada tahun 1970 sampai tahun 2000-an batik Laweyan mengalami mati suri sebagian besar pengusaha batik mengalami kebangkrutan dari sekitar 281 pengusaha yang masih bertahan tinggal 18 pengusaha. Untuk mengatasi hal tersebut, beberapa pengusaha batik Laweyan dapat mempertahankan diri dari kebangkrutan dengan memproduksi industri kerajinan printing-tulis, cap-tulis, dan batik tulis. Ketahanan kerajinan batik printing-tulis, cap-tulis, dan tulis murni tersebut membina hubungan-hubungan produksi antara pengusaha batik di kota dengan pengrajin batik rumahan di desa. Dari perkembangan industri batik ini ada yang menjadi ciri khas komunitas kampung batik Laweyan adalah sebagai kampung dagang. Karakteristik masyarakatnya sangat unik karena hampir keseluruhan berprofesi sebagai pedagang atau pengusaha yang menekuni usaha perbatikan. Hal ini dipandang sebagai sesuatu yang aneh ditengah kehidupan masyarakat Surakarta, yang umumnya bekerja dibidang pertanian dan birokrat kerajaan. Mayoritas jenis pekerjaan yang ditekuni, identitas masyarakat, nilai serta perilaku sosial, dan kebudayaannya tampak jelas sangat dipengaruhi jiwa entre peneurship (Mlajadipura, 1984). Dengan adanya perubahan kekayaan, maka menaikan status sosial mereka. Pada karakter pengusaha batik yang dahulunya masyarakat Laweyan sebagai wong lumrah atau orang kebanyakan, kini menjadi pengusaha batik yang disebut Juragan Batik dan perubahan ini juga terjadi pada status sosialnya. Pada masa kemerosotan batik Laweyan sikap mereka berubah menjadi masyarakat yang tertutup. Perubahanan juga diikuti perubahan topografinya yang dahulunya pola kawasan Kampung Batik Laweyan berbentuk memusat berubah menjadi berbentuk pola linear dan berubah lagi menjadi pola cluster (Priyatmono, 2004).

\section{Tekanan-Tekanan Struktural dan Kultural Dialami Pengusaha Batik Laweyan}

Pengusaha batik Laweyan terdiri dari pengusaha skala besar, menengah, dan kecil. Pasar untuk penjualan produk ketiga golongan pengusaha ini mempunyai sasaran yang hampir sama yaitu menjual batik ke pasar Klewer dan membuka showroom di Laweyan, sehingga terjadi persaingan yang tidak sehat. Para pengusaha skala besar mempunyai modal yang cukup sedangkan pengusaha menengah dan kecil mempunyai modal yang terbatas, sehingga keadaan seperti ini dapat menghambat perkembangan industri kecil dan menengah.

Perkembangan industri batik Laweyan tidak dapat dipisahkan dari perkembangan 
industri sejenis yang berada di sekitarnya. Di Surakarta industri tekstil meliputi kegiatan pertenunan, finishing, konveksi, dan sebagainya. Perkembangan industri tekstil maupun batik modern sebenarnya tidak hanya menimbulkan persaingan bagi batik tradisionil di Surakarta, khususnya Laweyan. Daerah-daerah pembatikan lainnya juga mengalami hal serupa. Industri tekstil dan batik printing mempunyai banyak pilihan desain dengan kualitas yang lebih baik serta harga yang lebih murah.

SejakJanuari2010mulaidiberlakukannya CAFTA (China Asean Free Trade Area) yaitu telah berlaku perdagangan bebas antara ASEAN dan China sehingga produk-produk China menjadi sangat mudah untuk masuk ke Indonesia. Apalagi sebagian besar produk China dikenai tarif nol persen untuk masuk ke Indonesia. Produk China yaitu berupa batik printing sudah banyak membanjiri pasar-pasar tradisional seperti Pasar Klewer. Dengan harga yang murah, motif bagus, dan kualitas bagus, maka banyak masyarakat yang lebih menyenangi produk China ini dibandingkan dengan produk batik tulis yang harganya mahal. Tanpa disadari omset penjualan batik tulis menjadi berkurang. Pengusaha batik Laweyan sampai saat ini belum merasakan dampak dari masuknya produk Cina terutama kain bermotif batik.

Dengan dibukanya kran globalisasi, maka pemerintah Indonesia perlu membentuk kebijakan baru untuk membantu produk lokal yang bersaing dengan produk China. Pemerintah Indonesia perlu membatasi produk China yang masuk untuk melindungi produsen-produsen lokal yang lambat laun semakin berkurang. Apalagi jika pemerintah tidak bergerak dengan cepat, maka dikuatirkan akan memberikan dampak yang sangat besar terhadap industri batik lokal.

Permintaan agar pemerintah segera melindungi industri lokal dinilai memiliki alasan yang kuat. Apalagi produk China memiliki kualitas yang baik bila dibandingkan dengan produk lokal. Jika tidak segera dilindungi oleh pemerintah, maka dikuatirkan banyak produsen lokal yang menutup usahanya dan berakibat pada angka pengangguran yang tinggi dari dalam negeri ini.

Salah satu penyebab kemrosotan industri batik tradisionil Laweyan adalah faktor bahan baku. Harga bahan baku dan bahan penolong yang pada tahun 2010 mengalami kenaikan tiga kali, menyebabkan banyak para pengusaha yang skala kecil menghentikan usahanya untuk sementara waktu. Sedangkan pengusaha skala besar cenderung untuk menumpuk persediaan bahan baku.

Berdasarkan peraturan pemerintah dalam hal ini Dinas Tenaga Kerja telah mengeluarkan peraturan mengenai upah tenaga kerja yang baru bahwa setiap pengusaha harus membayar karyawannya berdasarkan UMR (Upah Minimum Regional), padahal pada saat itu apabila pengusaha Laweyan belum mampu membayar tenaga kerja sesuai UMR, akhirnya banyak pengusaha yang gulung tikar, dan itupun masih harus memberi pesangon kepada karyawannya. Hal ini juga yang mempengaruhi mundurnya industri batik di Surakarta pada umumnya dan Laweyan pada khususnya. (Wawancara, H. Sulaiman, 10 Oktober 2010).

Kekurangan tenaga ahli baik batik tulis maupun batik capyang menyebabkan adanya kenaikan upah. Kekurangan ini disebabkan tidak adanya regenerasi, banyak keturunan dari pembatik maupun tenaga cap enggan untuk meneruskan usahanya dikarenakan pekerjaan ini kurang menjanjikan masa depan mereka sehingga perlu adanya perubahan-perubahan sebagai berikut: Pertama, Perubahan motif batik bahwa industri batik Laweyan dikenal sebagai penghasil batik tulis tradisional. Industri batik Laweyan tidak mempunyai produk yang terspesialisasi khusus dan cenderung terdiversifikasi karena memproduksi motif batik sesuai dengan pesanan konsumen dan pasar. Hal ini di satu sisi positif karena mampu merespon permintaan dengan cepat, namun di sisi lain hal ini di pandang negatif 
karena menghilangkan ciri khas tradisional batik Laweyan.

Kedua, Produk tekstil bermotif batik bahwa batik printing banyak diproduksi oleh perusahaan besar, sebenarnya batik printing bukan merupakan batik karena tidak melalui proses penggunaan malam, maka paling tepat adalah produk tekstil yang bermotifkan batik. Adanya kecenderungan motif batik printing mengangkat motif-motif batik tradisionil ke dalam bahan-bahan yang cukup halus, hal ini membuat konsumen yang tidak paham masalah batik menjadi terkelabuhi.

Ketiga, Perubahan pola konsumsi, di pasar domistik globalisasi menyebabkan terjadinya proses internasionalisasi sistem budaya dengan dampak langsung terhadap perilaku konsumsi masyarakat. Pergeseran pola konsumsi ini akan menggeser pula permintaan akan produk-produk nasional yang tidak memiliki ciri budaya "internasional". Banyaknya penawaranpenawaran produk luar negeri yang harganya murah serta kualitas dan motif menarik. Perubahan fundamental kedua berkenaan dengan dinamika pembangunan ekonomi nasional itu sendiri, yaitu transformasi struktur perekonomian dari ekonomi tradisional ke ekonomi modern, dari ekonomi agraris ke ekonomi industri.

Strategi kelangsungan usaha batik Laweyan, pengusaha batik Laweyan sebagian besar adalah industri batik skala kecil dan menengah, yang mana dalam menghadapi globalisasi diperlukan beberapa strategi prioritas yang digunakan, yang diarahkan dengan memperbaiki kelemahan dan memanfaatkan peluang yang ada. Strategi yang digunakan sebagai berikut: Pertama, Penguatan kerjasama, yaitu Pengembangan industri batik Laweyan tidak dapat dilakukan sendiri oleh pengusaha batik saja, tetapi memerlukan sinergitas semua pihak. Terjadinya kerjasama yang kuat antarpelakupelaku yang terkait dalam mengembangkan industri batik diperlukan satu visi bersama. Pelaku-pelaku yang terkait diantaranya pengusaha industri batik Laweyan yang terdiri dari perwakilan industri batik skala kecil, menengah, dan besar; industri pendukung (pembeli, pemasok bahan baku, bahan penolong); Pemerintah yaitu Bappeda, Dinas Perindustrian dan Perdagangan, Dinas Koperasi, Dinas Pariwisata; Lembaga Keuangan; Lembaga pendidikan dan pelatihan; asosiasi usaha; Lembaga bantuan pengembangan bisnis.

Kedua, Penguatan pasar, Penanganan pemasaran menjadi prioritas karena jika produk batik Laweyan mempunyai pasar yang jelas, maka akan terjadi kontinuitas proses produksi. Dengan demikian, usaha batik akan berkembang, permasalahan keuangan dapat teratasi, dan kesejahteraan tenaga kerja dapat meningkat. Untuk mempunyai pasar yang jelas setiap industri batik Laweyan harus mempunyai karakter batiknya (produk terspesialisasi).

Ketiga, Peningkatan kapasitas sumber daya manusia, Peningkatan kapasitas sumber daya manusia sangat penting bagi pengembangan industri batik Laweyan karena manusia merupakan penggerak, pemberi keputusan, dan pelaku dari setiap kegiatan. Usaha akan berkembang dengan baik jika pelaku tersebut memiliki motivasi, serta memiliki pendidikan dan pengetahuan akan manajemen usaha dan teknologi.

Keempat, Penciptaan iklim usaha yang kondusif, Penciptaan iklim usaha yang kondusif diperlukan untuk mewujudkan industri batik yang efisien, dinamis, berdaya saing, serta dapat menarik investor yang dapat membantu masalah permodalan yang banyak dihadapi oleh industri batik skala kecil. Terciptanya iklim usaha yang kondusif guna kelancaran pelaksanaan dan pengembangan usaha, terutama dalam menarik investor untuk berinvestasi di industri batik Laweyan.

Kelima, Penguatan social capital (Modal Sosial) pengusaha batik Laweyan, Pengertian modal sosial menurut Robert R.Putnam (1997) adalah sebuah barang publik (Public Good) yang dibangun oleh masyarakat. Sumber dari modal sosial adalah norma dan kepercayaan (trust) di mana kedua aspek 
tersebut yang mendasari kerjasama dan aksi bersama (collective action) untuk mencapai kemanfaatan.

Modal sosial ini merupakan kunci perekat yang mengikat warga masyarakat secara bersama menjadi kumpulan dan jaringan sosial, institusi, norma-norma, (seperti kerjasama) dan nilai-nilai atau atribut sosial (kususnya trust). Modal sosial pengusaha batik Laweyan terlihat apabila dari beberapa pengusaha batik Laweyan mempunyai kesulitan tentang pengadaan bahan baku mori. Untuk itu, pegusaha tersebut membeli dengan mencicil ataupun dibayar setelah barang laku. Dalam sosial kapital pengusaha batik Laweyan memegang teguh kepercayaan (trust) yang telah diberikan oleh pengusaha lain sehingga bila membutuhkan bantuan bahan baku dapat meminjam pengusaha lain.

\section{SIMPULAN}

Berdasarkan hasil dari pembahasan yang telah diuraikan di atas dapat disimpulkan sebagai berikut:

1. Perubahan yang terjadi pada pengusaha batik Laweyan yang dimulai dari awal berdirinya industri batik, masa kejayaan, dan masa kemerosotan batik Laweyan berpengaruh pada perubahan pola kawasan yaitu mulai pola kawasan memusat yaitu pasar Laweyan sebagai pusat kawasan dan pada saat dimulainya industri batik, berubah menjadi linier yaitu terbentuknya kelompok komunitas pekerja batik dan pengusaha batik, dan pada tahun 2003 sampai sekarang pola kawasan berbentuk Cluster yaitu disebabkan karena kemajuan teknologi, proses batik dapat diselesaikan dalam satu unit industri (rumah). Pengusaha batik dan buruh tidak lagi membentuk kelompok besar pemukiman tersendiri.

2. Perjalanan pengusaha batik Laweyan memerlukan waktu yang lama, dari mulai batik diperkenalkan di Laweyan pada masa Kyai Ageng Henis, berkembang padaawalabad ke20, kejayaan usahabatik yang pada puncaknya tahun 1960 dan kebangkrutan sekitar tahun 1970 sampai 2000 selalu mewarnai usaha tersebut silih berganti. Semakin jaya atau berkembang usaha tersebut, maka semakin kuat pula tekanan-tekanan yang dirasakan, begitu juga dengan pengusaha batik Laweyan, berbagai tekanan-tekanan yang dirasakan tidak membuat pengusaha patah arang, tetapi dari pengalamanpengalaman yang sudah dilalui membuat bertambah kokohnya usaha tersebut. Tekanan-tekanan yang dirasakan pada saat ini, baik tekanan struktural maupun kultural adalah sebagai berikut adanya penekanan dari pengusaha skala besar terhadap pengusaha skala menengah dan kecil karena mempunyai pasar yang sama, persaingan dengan industri tekstil dan batik modern, dibukanya kran globalisasi oleh pemerintah serta tidak ada perlindungan dari pemerintah akan masuknya barang-barang dari China, harga bahan baku yang tidak stabil, upah tenaga kerja yang tinggi. Sedangkan tekanan kultural yang dirasakan oleh pengusaha batik Laweyan adalah adanya perubahan motif batik dari tradisional ke modern, produksi tekstil bermotif batik, dan perubahan pola konsumsi masyarakat.

3. Strategi yang telah digunakan dalam pengembangan komoditas oleh pengusaha batik Laweyan adalah penguatan karakter batik masingmasing pengusaha, apabila setiap industri batik mempunyai karakter sendiri-sendiri pada batiknya, maka akan mengurangi persaingan diantara pengusaha. Diharapkan pula dengaan penguatan karakter batik setiap pengusaha, maka akan memperkuat komoditas batik Laweyan sendiri.

\section{DAFTAR PUSTAKA}

Abdullah, Irwan, 1994, The Muslim Businessmen of Jatinom, Universiteit Van Amsterdam, Academisch Proefschrift. 
Ansoff, H. I., McDonnell, E., 1990, Implanting Strategic Management, New York: Prentice Hall.

Argyo Demartoto, 1999, Persepsi Ekonomi dan Sosial Budaya Para Pengusaha Batik Laweyan, Penelitian: Universitas Sebelas Maret.

Geertz Clifford, 1965, Agriculture Involution : The Process of Ecological Change, Berkeley University Press.

Geertz Clifford, 1977, Peddleers and Prices, The University of Chicago Press .

Hart,Gillian, 1989,. "Agrarian Change in the Context of State Patronage", in Hart, G., Andre Turton, and Benjamin White (eds.), Agrarian Transformations:Local Processes and the State in Southeast Asia, Berkeley: University of California Press.

Hamel, Gary and Prahalad, C.K, 1996, Competing in the new Economy : Managing out of Bounds, Strategic Management Journal, 17 (3): 237

Karba'a, Tiar, 2010, Ekspansi Produk China Memberi Tekanan Kepada Produk Lokal. Suara Pembaca.

L. Laeyendecker, 1983, Tata, Perubahan, dan Ketimpangan: Suatu Pengantar Sejarah Sosiologi, (Orde, Verandering, Ogelijkheid: Een Inleiding in De Geschiedenis van De Sociologie), alih bahasa Sumekto, Jakarta: Gramedia.

Mlayadipuro, 1984, Sejarah Kyai Ageng Anis-Kyai Ageng Laweyan, Uripurip (penyunting : Santoso,Suwito) Museum Radya Pustaka Surakarta.

Porter.Michael E, 1997, Strategi Bersaing (terj), Jakarta : Erlangga.
Priyatmono, Alpha Febela, 2004, Konsep Awal Pengembangan Kampung Wisata Batik Laweyan, Penelitian: Universitas Muhammadyah Surakarta.

Priyatmono, Alpha Febela, 2004, Studi Kecenderungan Perubahan Morfologi Kawasan Kampung Laweyan Surakarta, Thesis: Program Pascasarjana Universitas Gajah Mada Yogyakarta.

Philip Kotler, 2000, Marketing Management, The Millennium Edition, Prentice Hall International, Inc.

Prasetyo, Anindito, 2010, Batik Karya Agung Warisan Budaya Dunia, Pura Pustaka.

Robert D. Putnam,1993, Making Democracy Work: Civic Traditions in Modern Italy, Princeton: Princeton University Press.

Soekanto Soerjono, 1983, Teori Sosiologi Tentang Perubahan Sosial, Penerbit Ghalia Indonesia.

Sumodiningrat, Gunawan, 1999, Pemulihan Ekonomi dan Ekonomi Kerakyatan dalam Dialog Budaya Sebagai Terapi Sistem Sosial Budaya dan pemulihan Kehidupan Ekonomi Wilayah, Pemda Tk I dan UNS. Dialog Budaya.

Sumodiningrat, Gunawan, 2008, Mencintai Bangsa dan Negar, PT. Sarana Komunikasi Utama.

Suryanti, Nopvi, 2009, Potensi Kampung Batik Laweyan Sebagai Wisata Industri Dalam Mendukung Pendapatan Asli Daerah. Penelitian.

Wijaya, Mahendra, 2008, Ekonomi Komersial Ganda:Perkembangan Kompleksitas Jaringan Sosial Ekonomi Perbatikan di Surakarta, Disertasi: Program Doktor Ilmu Sosial Sekolah Pasca Sarjana Universitas Gadjah Mada: Yogyakarta. 